\title{
Tumorigenicity of the miR-17-92 cluster distilled
}

\author{
Gijs van Haaften and Reuven Agami ${ }^{1}$ \\ Division of Gene Regulation, The Netherlands Cancer Institute, 1066 CX Amsterdam, The Netherlands; and Center \\ for Biomedical Genetics, 3584 CG Utrecht, The Netherlands
}

The miR-17-92 gene cluster, with its six different mature microRNAs (miRNAs), has an established oncogenic function. However, the oncogenic contribution of each individual miRNA in the cluster has not been assigned. Two studies published in the December 15, 2009, issue of Genes \& Development by $\mathrm{Mu}$ and colleagues (pp. 28062811) and Olive and colleagues (pp. 2839-2849) dissected the miR-17-92 cluster to its individual miRNA components and identified their relative contributions to oncogenic transformation in mouse model systems.

MicroRNAs (miRNAs) are genes involved in normal development and cancer (Croce 2009). They inhibit gene expression through a Watson-Crick interaction with 3' untranslated regions (UTRs) of messenger RNAs (mRNAs). The interaction of miRNAs with mRNAs depends to a large extent on a 7-nucleotide (nt) "seed" sequence at their 5 ' end (nucleotides 2-8). Both bioinformatics and experimental analyses have indicated that miRNAs may regulate a large proportion of proteincoding genes (Stark et al. 2005; Baek et al. 2008; Selbach et al. 2008).

The human miR-17-92 cluster is located on 13q31.3, a locus that is frequently amplified in lymphomas (Ota et al. 2004; Hayashita et al. 2005; Rinaldi et al. 2007) and colorectal cancer (Diosdado et al. 2009). The polycistronic miRNA cluster produces a single primary transcript yielding the six mature miRNAs miR-17, miR-18a, miR-19a, miR-20a, miR-19b, and miR-92a, which are tightly grouped within an 800-base-pair (bp) genomic region (Fig. 1). The sequences of the mature miRNAs are highly conserved in all vertebrates. The human miR17-92 cluster is located in the third intron of the primary transcript C13orf25. Interestingly, despite the high conservation of miRNA sequences, the exonic sequences of C13orf 25 are not conserved across species, indicating that it is most likely that the only function of the transcript is the production of miRNAs (Mendell 2008).

[Keywords: MicroRNAs; Myc; cancer; apoptosis; mir-17-92; mir-19] ${ }^{1}$ Corresponding author.

E-MAIL r.agami@nki.nl; FAX 31-20-512-2029.

Article is online at http://www.genesdev.org/cgi/doi/10.1101/gad.1887110.
The six miRNAs of the miR-17-92 cluster can be grouped into four different families based on their seed sequence homology; namely, miR-17/miR-20a, mir-18a, miR-19a/19b, and miR-92a (Fig. 1A). The miRNAs contained in the cluster are overexpressed in a variety of cancers, both hematopoietic and solid tumors such as those derived from breast, lung, pancreas, colon, prostate, and stomach (Volinia et al. 2006). Each of those miRNA families is predicted to regulate different cellular targets. However, the individual contribution of each miRNA to the oncogenic properties of the miR cluster is unclear.

Ancient gene duplications gave rise to two polycistronic miR-19-72 paralogs in mammals: the miR-106b-25 and mir-106a-363 clusters. Of these, overexpression of the miR-106b-25 cluster was shown to interfere with cell cycle arrest and apoptosis when overexpressed in cancer cells (Petrocca et al. 2008). The miR-106b-25 cluster is located on human chromosome 7 and contains miR-106b, miR-93, and miR-25. The first two belong to the mir-17 family and the last one is homologous to miR-92a. Mice deficient for the miR-17-92 cluster die shortly after birth with lung and heart defects. Targeted deletion of the miR-17-92 cluster in the hematopoietic compartment showed that the cluster is essential for B-cell development (Ventura et al. 2008). Knockout mice for the miR106b-25 cluster and the miR-106a-363 showed no obvious phenotypes; however, combined deletion of both miR106b-25 and miR-17-92 showed stronger developmental phenotypes than both single knockouts, indicating that both clusters have some overlapping functions.

Additional indications for an oncogenic role of the miR-17-92 cluster come from the occurrence of common integration sites in several mouse models for retroviralinduced leukemia (Wang et al. 2006; Cui et al. 2007). Interestingly, the miR-106a-363 locus is targeted by retroviral insertions in a mouse model for retrovirally induced lymphomas (Landais et al. 2007). Moreover, Uren et al. (2008) described an extensive study characterizing retroviral insertions in tumors isolated from wild-type and tumor-prone mice ( $p 19^{A R F-1-}$ and $\left.p 53^{-/-}\right)$. The only miRNA cluster targeted by retroviral insertions was the miR-106a-363 locus, and insertions occurred more often in $p 19^{A R F-/-}$ and $p 53^{-/-}$mice, indicating that mutation of the miR-106a-363 locus is selected for in cells that lack the p19 $9^{\mathrm{ARF}}$-p53 tumor suppression pathway. 
A

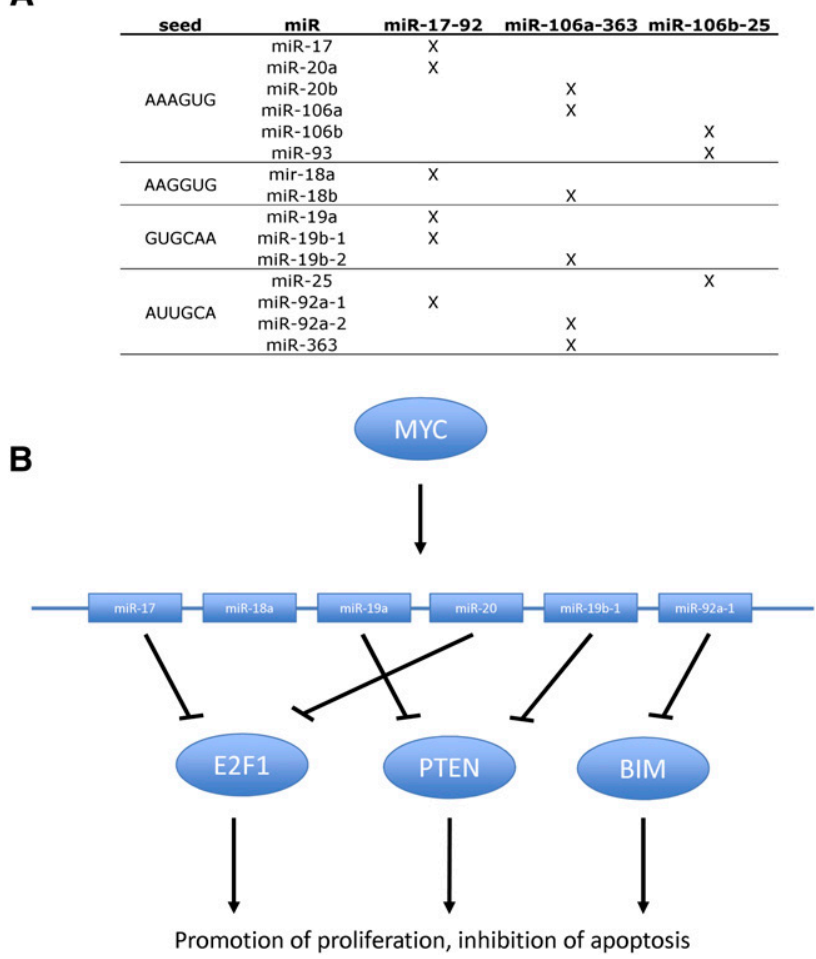

Figure 1. (A) Clustering of the miRNAs of miR-17-92 and its paralogous clusters based on the regions most important for target selection (the seed sequences, nucleotides 2-7 of the mature miR). (B) Role of the miR-17-92 cluster in oncogenesis. The miR-17-92 cluster is a direct transcriptional target of c-Myc. miR-17/20a targets E2F1, a regulator of the cell cycle and apoptosis. miR-92 targets BIM, a proapoptotic gene that counteracts the anti-apoptotic activity of genes such as Bcl2. miR-19 targets PTEN, a negative regulator of the oncogenic prosurvival PI3K/AKT signaling pathway.

The genomic amplifications and overexpression of the miR-17-92 cluster have attracted attention in the cancer community. The laboratories of Hannon and He (He et al. 2005) showed that the miR-19-72 cluster has direct oncogenic activity; it cooperates with c-Myc in a mouse model of B-cell lymphomas. Overexpression of this miRNA cluster dramatically enhanced the onset and progression of the lymphomas by inhibiting the high level of apoptosis usually seen in c-Myc-induced lymphomas. Concurrently, the miR-17-92 cluster itself was shown to be a direct transcriptional target of $\mathrm{c}-\mathrm{Myc}$, indicating a balancing effect and a negative feedback loop operating between the two (O'Donnell et al. 2005).

As the four different miRNA types encoded by the miR17-92 cluster are predicted and likely to have multiple different cellular targets, it is of interest to decipher the individual contribution of the different components of the cluster in malignant transformation. To tackle this problem, the groups of Ventura (Mu et al. 2009) and He (Olive et al. 2009) made use of a cancer mouse model of $\mathrm{c}-\mathrm{Myc}$ gene expressed under the control of the immunoglobulin heavy-chain enhancer $(\mathrm{E} \mu)$, which develops B-cell lymphomas by 4-6 mo of age (Adams et al. 1985).
Similarly, haematopoietic stem cells (HSCs) derived from fetal livers of $\mathrm{E} \mu-M y c$ transgenic mice generate B-cell lymphomas with comparable latency when transplanted into lethally irradiated recipients (Schmitt et al. 2002; Hemann et al. 2003). The transplantations of tumorprone HSCs allow elegant genetic approaches without the need to generate full transgenic animals.

$\mathrm{Mu}$ et al. (2009) took advantage of their previously generated inducible deletion of the entire miR-17-92 cluster (Ventura et al. 2008). They found that deletion of the complete miR-17-92 cluster slows c-Myc-induced oncogenesis. This effect was rescued by reintroduction of the full cluster, but not by the cluster lacking miR-19a/ 19b. This identified miR-19 as the most important miRNA of the cluster in this mouse model. Reintroduction of miR-19a/19b largely rescued tumorigenicity, but not to the same extent as the full cluster, indicating that other members of the cluster also contribute to the protumorigenic activity of the miR-17-92 cluster.

Olive et al. (2009) approached the dissection of the miR-17-92 cluster from the opposite side, by overexpression of different miRNA components in the $\mathrm{E} \mu-\mathrm{Myc}$ induced B-cell lymphomas. They found that overexpression of the entire cluster, the cluster without miR-92, but not when miR-19a and miR-19b were lost, enhanced oncogenesis. Thus, also here lymphomagenesis was to a large extent dependent on functional miR-19 seed sequences.

After the identification of miR-19 as the most important miRNA of the miR-17-92 cluster in c-Myc-induced lymphomagenesis, both groups studied the mRNA targets of miR-19. Mu et al. (2009) analyzed changes in gene expression in a lymphoma cell line derived from a mouse homozygous for the inducible deletion of the miR-17-92 cluster and heterozygous for $\mathrm{E} \mu-\mathrm{Myc}$. They found 568 genes to be both up-regulated upon deletion of the entire cluster and down-regulated by the reintroduction of either the full cluster or miR-19a/19b only. Of these genes, 95 contained predicted miR-19 seed sequences, of which 46 were selected for functional validation. These 46 genes were knocked down and tested for enhancement of proliferation in a lymphoma cell line. The strongest effect was seen for knockdown of PTEN, and more modest effects were seen for knockdown of Sbf2, Bcl7a, and Rnf44.

Olive et al. (2009) focused on known targets of miR-19, with PTEN being a good candidate (Lewis et al. 2003). They showed that PTEN could indeed be down-regulated by miR-19, in a manner dependent on intact miR-19predicted binding sites in its 3'UTR. Moreover, PTEN protein levels in the mouse model are lowered in response to elevated levels of miR-19. Altogether, both Olive et al. (2009) and Mu et al. (2009) conclude that miR-19 is the main oncogenic component of the cluster, and that suppression of PTEN explains most of the oncogenic effects in the $\mathrm{E} \mu-M y c$ model.

Pten is one of the most frequently mutated tumor suppressors in a variety of sporadic and heritable human cancers. PTEN is a crucial negative regulator of the highly oncogenic prosurvival PI3K/AKT signaling pathway. Mu 
et al. (2009) show by immunoblotting that Pten downregulation by overexpression of miR-19 indeed leads to activation of the Akt-mammalian target of rapamycin (mTOR) pathway in NIH-3T3 cells and in lymphomas isolated from $\mathrm{E} \mu-\mathrm{Myc}$ mice. Monoallelic mutations in Pten have been estimated to occur in $50 \%-80 \%$ of endometrial carcinoma, glioblastoma, and prostate tumors and in $30 \%-50 \%$ of lung, breast, and colon tumors (Salmena et al. 2008). The high rates of monoallelic mutations in human cancer indicate that Pten functions as a haploinsufficient tumor suppressor. As overexpression of a miRNA targeting PTEN could potentially drop PTEN protein to levels comparable with or lower than those seen in monoallellic-inactivating mutations in the pten gene, the effect of miR-19 on PTEN can fully explain its oncogenic character.

Having said that, the discovery of miR-19 as the main oncogenic miRNA of the miR17-92 cluster with PTEN as its main target is surprising, since other miRNAs from the miR-17-92 cluster have also been described to control important tumor suppression pathways. The two miR-17 family members of the miR-17-92 cluster, miR-17 and miR-20a, have been reported to down-regulate the activating members of the E2F family of transcription factors (E2F1, E2F2, and E2F3), which are regulators of the cell cycle and apoptosis. The activating members of the E2F family induce genes driving $\mathrm{G}_{1}$-to-S-phase transition. On the other hand, high levels of E2F proteins, especially E2F1, can induce apoptosis, which functions as an emergency brake for overproliferating cells. The miR-17 family was proposed to disable this emergency brake function of E2F factors and thus stimulate cancerous growth (O'Donnell et al. 2005; Sylvestre et al. 2007; Woods et al. 2007).

The cyclin-dependent kinase inhibitor CDKN1a/p21, a potent inhibitor of the $\mathrm{G}_{1-}$ to S-phase checkpoint, is another target of the miR-17 family. Overexpression of miR-106b, a homolog of miR-17, and the entire host miR-106b-25 cluster, can promote S-phase entry in some cell systems (Ivanovska et al. 2008) and override TGF $\beta$ induced cell cycle arrest (Petrocca et al. 2008). Conversely, inhibition of miR-106b can delay entry into $S$ phase and increase sensitivity to TGF $\beta$. In addition, BCL2L11/BIM is another target gene of the miR-17-92 cluster and paralog clusters. BIM is a proapoptotic gene that counteracts the anti-apoptotic activity of genes such as Bcl2. Indeed, BIM is a suppressor of Myc-induced lymphomas in the E $\mu-M y c$ model (Egle et al. 2004). The BIM-3'UTR contains binding sites for multiple members of the miR-17-92 cluster and related clusters. Although regulation of BIM by the miR-17-92 cluster was demonstrated convincingly, the exact miRNA involved in this action was hard to determine due to an abundance of different miRNA-binding sites in the $3^{\prime}$ UTR of BIM (Koralov et al. 2008; Petrocca et al. 2008; Ventura et al. 2008; Xiao et al. 2008).

Several other cancer genes were described as being regulated by members of the miR-17-92 cluster: Cyclin D1 (CCND1) functions in a regulatory feedback loop with miR-17/20 in breast cancer (Yu et al. 2008), p63 promotes proliferation due to isoform-specific regulation by miR-92 (Manni et al. 2009), and miR-92a controls the von Hippel-Lindau (VHL) gene product in chronic lymphocytic leukemia (Ghosh et al. 2009). Also, high levels of miR-92a have been shown to be important for angiogenesis in ischemic tissues, implicating a potential role for miR-92a in tumor angiogenesis (Bonauer et al. 2009).

The oncogenic contributions of other miRNAs and other target genes in tumors with miR-17-92 overexpression remain to be determined. Also, the oncogenic impact of the different miRNAs of the miR-17-92 cluster is likely to differ per tumor type. The studies discussed here show that the oncogenic function of the miR-19-72 cluster in a mouse model for Myc-induced lymphomagenesis can be largely attributed to miR-19 and its effect on PTEN. However, these studies looked only at the effects of the miR-17-92 cluster in a single oncogenic mouse model. The impact of the individual components of the miR-1792 cluster in other systems, especially in human tumors, remains to be shown. At the least, an evolutionarily functional conservation of the miR-19/PTEN/apoptosis axis from mouse to frog suggests that these new findings are likely to be relevant to human cancer.

\section{Acknowledgments}

We thank the Dutch Cancer Society (KWF) for funding.

\section{References}

Adams JM, Harris AW, Pinkert CA, Corcoran LM, Alexander WS, Cory S, Palmiter RD, Brinster RL. 1985. The c-myc oncogene driven by immunoglobulin enhancers induces lymphoid malignancy in transgenic mice. Nature 318: 533-538.

Baek D, Villen J, Shin C, Camargo FD, Gygi SP, Bartel DP. 2008. The impact of microRNAs on protein output. Nature 455: 64-71.

Bonauer A, Carmona G, Iwasaki M, Mione M, Koyanagi M, Fischer A, Burchfield J, Fox H, Doebele C, Ohtani K, et al. 2009. MicroRNA-92a controls angiogenesis and functional recovery of ischemic tissues in mice. Science 324: 1710 1713.

Croce CM. 2009. Causes and consequences of microRNA dysregulation in cancer. Nat Rev Genet 10: 704-714.

Cui JW, Li YJ, Sarkar A, Brown J, Tan YH, Premyslova M, Michaud C, Iscove N, Wang G), Ben-David Y. 2007. Retroviral insertional activation of the Fli-3 locus in erythroleukemias encoding a cluster of microRNAs that convert Epo-induced differentiation to proliferation. Blood 110: 2631-2640.

Diosdado B, van de Wiel MA, Terhaar Sive Droste JS, Mongera S, Postma C, Meijerink WJ, Carvalho B, Meijer GA. 2009. MiR17-92 cluster is associated with $13 \mathrm{q}$ gain and c-myc expression during colorectal adenoma to adenocarcinoma progression. Br J Cancer 101: 707-714.

Egle A, Harris AW, Bouillet P, Cory S. 2004. Bim is a suppressor of Myc-induced mouse B cell leukemia. Proc Natl Acad Sci 101: 6164-6169.

Ghosh AK, Shanafelt TD, Cimmino A, Taccioli C, Volinia S, Liu CG, Calin GA, Croce CM, Chan DA, Giaccia AJ, et al. 2009. Aberrant regulation of $\mathrm{pVHL}$ levels by microRNA promotes the HIF/VEGF axis in CLL B cells. Blood 113: 5568-5574.

Hayashita Y, Osada H, Tatematsu Y, Yamada H, Yanagisawa K, Tomida S, Yatabe Y, Kawahara K, Sekido Y, Takahashi T. 
2005. A polycistronic microRNA cluster, miR-17-92, is overexpressed in human lung cancers and enhances cell proliferation. Cancer Res 65: 9628-9632.

He L, Thomson JM, Hemann MT, Hernando-Monge E, Mu D, Goodson S, Powers S, Cordon-Cardo C, Lowe SW, Hannon GJ, et al. 2005. A microRNA polycistron as a potential human oncogene. Nature 435: 828-833.

Hemann MT, Fridman JS, Zilfou JT, Hernando E, Paddison PJ, Cordon-Cardo C, Hannon GJ, Lowe SW. 2003. An epi-allelic series of p53 hypomorphs created by stable RNAi produces distinct tumor phenotypes in vivo. Nat Genet 33: 396-400.

Ivanovska I, Ball AS, Diaz RL, Magnus JF, Kibukawa M, Schelter JM, Kobayashi SV, Lim L, Burchard J, Jackson AL, et al. 2008. MicroRNAs in the miR-106b family regulate p21/CDKN1A and promote cell cycle progression. Mol Cell Biol 28: 21672174.

Koralov SB, Muljo SA, Galler GR, Krek A, Chakraborty T, Kanellopoulou C, Jensen K, Cobb BS, Merkenschlager M, Rajewsky N, et al. 2008. Dicer ablation affects antibody diversity and cell survival in the B lymphocyte lineage. Cell 132: $860-874$.

Landais S, Landry S, Legault P, Rassart E. 2007. Oncogenic potential of the miR-106-363 cluster and its implication in human T-cell leukemia. Cancer Res 67: 5699-5707.

Lewis BP, Shih IH, Jones-Rhoades MW, Bartel DP, Burge CB. 2003. Prediction of mammalian microRNA targets. Cell 115: 787-798.

Manni I, Artuso S, Careccia S, Rizzo MG, Baserga R, Piaggio G, Sacchi A. 2009. The microRNA miR-92 increases proliferation of myeloid cells and by targeting p63 modulates the abundance of its isoforms. FASEB J 23: 3957-3966.

Mendell JT. 2008. miRiad roles for the miR-17-92 cluster in development and disease. Cell 133: 217-222.

Mu P, Han Y-C, Betel D, Yao E, Squatrito M, Ogrodowski P, de Stanchina E, D'Andrea A, Sander C, Ventura A. 2009. Genetic dissection of the miR-17 92 cluster of microRNAs in Mycinduced B-cell lymphomas. Genes \& Dev 23: 2806-2811.

O'Donnell KA, Wentzel EA, Zeller KI, Dang CV, Mendell JT. 2005. c-Myc-regulated microRNAs modulate E2F1 expression. Nature 435: 839-843.

Olive V, Bennett MJ, Walker JC, Ma C, Jiang I, Cordon-Cardo C, Li Q-J, Lowe SW, Hannon GJ, He L. 2009. miR-19 is a key oncogenic component of mir-17-92. Genes \& Dev 23: 28392849.

Ota A, Tagawa H, Karnan S, Tsuzuki S, Karpas A, Kira S, Yoshida Y, Seto M. 2004. Identification and characterization of a novel gene, C13orf25, as a target for 13q31-q32 amplification in malignant lymphoma. Cancer Res 64: 3087-3095.

Petrocca F, Vecchione A, Croce CM. 2008. Emerging role of miR-106b-25/miR-17-92 clusters in the control of transforming growth factor $\beta$ signaling. Cancer Res 68: 8191-8194.

Rinaldi A, Poretti G, Kwee I, Zucca E, Catapano CV, Tibiletti MG, Bertoni F. 2007. Concomitant MYC and microRNA cluster miR-17-92 (C13orf25) amplification in human mantle cell lymphoma. Leuk Lymphoma 48: 410-412.

Salmena L, Carracedo A, Pandolfi PP. 2008. Tenets of PTEN tumor suppression. Cell 133: 403-414.

Schmitt CA, Fridman JS, Yang M, Lee S, Baranov E, Hoffman RM, Lowe SW. 2002. A senescence program controlled by p53 and p16INK4a contributes to the outcome of cancer therapy. Cell 109: 335-346.

Selbach M, Schwanhausser B, Thierfelder N, Fang Z, Khanin R, Rajewsky N. 2008. Widespread changes in protein synthesis induced by microRNAs. Nature 455: 58-63.

Stark A, Brennecke J, Bushati N, Russell RB, Cohen SM. 2005. Animal microRNAs confer robustness to gene expression and have a significant impact on 3'UTR evolution. Cell 123: 1133-1146.

Sylvestre Y, De Guire V, Querido E, Mukhopadhyay UK, Bourdeau V, Major F, Ferbeyre G, Chartrand P. 2007. An E2F/miR-20a autoregulatory feedback loop. J Biol Chem 282: 2135-2143.

Uren AG, Kool J, Matentzoglu K, de Ridder J, Mattison J, van Uitert M, Lagcher W, Sie D, Tanger E, Cox T, et al. 2008. Large-scale mutagenesis in p19(ARF)- and p53-deficient mice identifies cancer genes and their collaborative networks. Cell 133: 727-741.

Ventura A, Young AG, Winslow MM, Lintault L, Meissner A, Erkeland SJ, Newman J, Bronson RT, Crowley D, Stone JR, et al. 2008. Targeted deletion reveals essential and overlapping functions of the miR-17 through 92 family of miRNA clusters. Cell 132: 875-886.

Volinia S, Calin GA, Liu CG, Ambs S, Cimmino A, Petrocca F, Visone R, Iorio $M$, Roldo C, Ferracin $M$, et al. 2006. A microRNA expression signature of human solid tumors defines cancer gene targets. Proc Natl Acad Sci 103: 22572261.

Wang CL, Wang BB, Bartha G, Li L, Channa N, Klinger M, Killeen N, Wabl M. 2006. Activation of an oncogenic microRNA cistron by provirus integration. Proc Natl Acad Sci 103: 18680-18684.

Woods K, Thomson JM, Hammond SM. 2007. Direct regulation of an oncogenic micro-RNA cluster by E2F transcription factors. J Biol Chem 282: 2130-2134.

Xiao C, Srinivasan L, Calado DP, Patterson HC, Zhang B, Wang J, Henderson JM, Kutok JL, Rajewsky K. 2008. Lymphoproliferative disease and autoimmunity in mice with increased miR-17-92 expression in lymphocytes. Nat Immunol 9: 405414.

Yu Z, Wang C, Wang M, Li Z, Casimiro MC, Liu M, Wu K, Whittle J, Ju X, Hyslop T, et al. 2008. A cyclin D1/microRNA $17 / 20$ regulatory feedback loop in control of breast cancer cell proliferation. J Cell Biol 182: 509-517. 


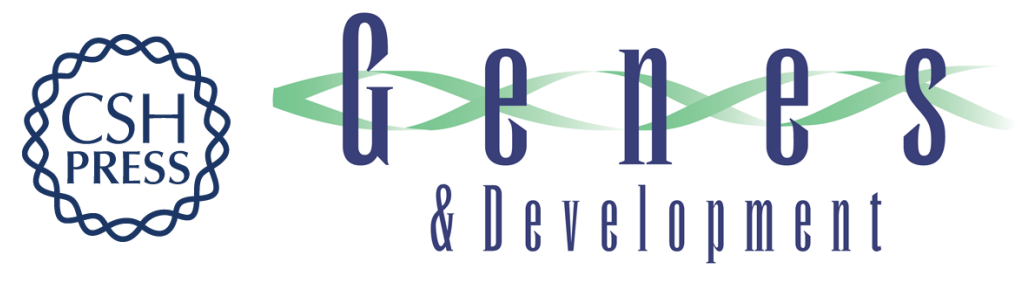

\section{Tumorigenicity of the miR-17-92 cluster distilled}

Gijs van Haaften and Reuven Agami

Genes Dev. 2010, 24:

Access the most recent version at doi:10.1101/gad.1887110

\section{Related Content Genetic dissection of the miR-17<92 cluster of microRNAs in Myc-induced B-cell lymphomas \\ Ping Mu, Yoon-Chi Han, Doron Betel, et al. \\ Genes Dev. December, 2009 23: 2806-2811 miR-19 is a key oncogenic component of mir-17-92 \\ Virginie Olive, Margaux J. Bennett, James C. Walker, et al. \\ Genes Dev. December , 2009 23: 2839-2849 \\ References This article cites 35 articles, 16 of which can be accessed free at: \\ http://genesdev.cshlp.org/content/24/1/1.full.html\#ref-list-1 \\ Articles cited in: \\ http://genesdev.cshlp.org/content/24/1/1.full.html\#related-urls \\ License Email Alerting
Service $\begin{aligned} & \text { Receive free email alerts when new articles cite this article - sign up in the box at the top } \\ & \text { right corner of the article or click here. }\end{aligned}$}

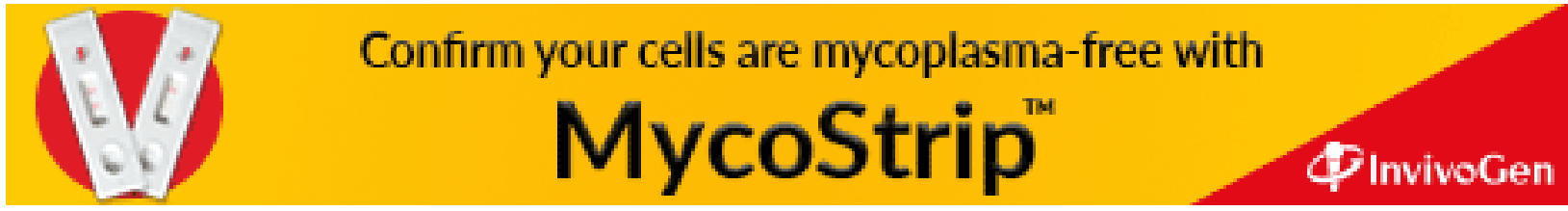

